\title{
CHEMICAL COMPOSITION OF THE ESSENTIAL OILS OF SALVIA SPP. LEAVES
}

\author{
Musa TurKmen* \\ Department of Field Crops, Faculty of Agriculture, Hatay Mustafa Kemal University, \\ Hatay, Turkey
}

Keywords: Sage, Essential oil, Chemical composition, Salvia aramiensis, Salvia fruticosa, Salvia tomentosa, Salvia officinalis

\begin{abstract}
The chemical composition of the hydrodistilled essential oils of four Salvia spp. were analysed by GCMS. Three of them (Salvia aramiensis Rech. fil., Salvia fruticosa Mill., Salvia tomentosa Mill.) analyzed in this study grow naturally in the Hatay flora. On the other hand, S. aramiensis is an endemic plant in Hatay flora. Fourth species (Salvia officinalis L.) is not growing in the flora of Turkey, but is only cultivated. The highest essential oil content $(5.31 \%)$ was found in S. aramiensis and the least $1.68 \%$ was detected in $S$. officinalis. Eucalyptol was the main constituent for S. aramiensis, S. fruticosa and S. tomentosa. While this component was $58.65 \%$ in $S$. aramiensis, it was determined as 44.70 and $34.97 \%$ in $S$. tomentosa and $S$. fruticosa, respectively. In $S$. officinalis, the main constituent was determined as $\delta$-Thujone $(33.83 \%)$ and camphor $(21.46 \%)$. Eucalyptol has been identified as the main composition in sage species which is grown in flora.
\end{abstract}

\section{Introduction}

Salvia genus with about 900 species is one of the most largest members of Lamiacea in the world (Askun et al. 2010) The species of Salvia were represented in Turkey by 89 species and 94 taxa and 45 which are endemic (Davis 1982, Baser 2002). Davis (1982) reported that there are 24 species in Hatay flora and 4 of these species are endemic.

Salvia species are commonly known as "Adacayi", "Salba" and/or "Dadirak" by the local people in Anatolia and Mediterranean region and used in folk medicine for the treatment of various diseases since ancient times (Jimenez et al. 1986, Askun et al. 2010). Salvia tomentosa Mill. poured onto the open cuts, $S$. fruticosa Mill. tea is widely used to cure colds and stomach aches (Yesilada et al. 1995, Demirci et al. 2002). Salvia officinalis L. is one of the most important culinary herbs and its essential oil is important for the pharmaceutical industry (Kelen and Tepe 2008). Salvia aramiensis Rech. fil. is widely consumed as an important tea and spice plant (Davis 1982).

It is reported that essential oils of these Salvia species contain many useful secondary metabolites such as terpenes, phenolic compounds and their derivatives (Tepe et al. 2007). Essential oils represent a rich potential source for alternative and natural control agents due to their antimicrobial, insecticidal, repellent and/or nutritional deterrent effects (Sener et al. 2009). However, the high content of camphor and thujone of these sage species, except Salvia aramiensis Rech. fil., limits their use as tea and spice in the food industry due to their toxic and carcinogenic effects (Manoguerra et al. 2006, Böszörmenyi et al. 2009, Shahabi et al. 2012, Pelkonen et al. 2013). It was reported the thujone ratio of $S$. fruticosa Mill. and both camphor and thujone ratio of Salvia aramiensis Rech. fil. is low (Lamaison et al. 1991, Cuvelier et al. 1994, Lawrence 1998, Demirci et al. 2002, Karaman. et al. 2007). It is clear that the composition of essential oil, oil and

*Author for correspondence: <turkmenmusa@hotmail.com>. 
protein can be affected by factors such as varieties and location (Mert et al. 2005). However, no comprehensive study has been found in which the essential oil contents and compositions of $S$. aramiensis Rech. fil., S. fruticosa Mill., S. tomentosa Mill. and S. officinalis L. have been studied. Therefore, the present study was aimed to investigate essential oil content and chemical composition of these four Salvia spp.

\section{Materials and Methods}

Sage plant samples used in the study were collected from different natural flora in Hatay province of Turkey. The plant identification was done by Dr. I. Üremis (Head of the Herbology's Department). Herbarium specimen was deposited for preservation at the Herbarium Collection of Field Crops Department at Hatay Mustafa Kemal University. The sage plants (S. aramiensis, $S$. fruticosa, S. tomentosa), which are naturally found at an altitude of $170-400 \mathrm{~m}$ in the flora of Hatay region (Turkey), were collected and dried at $35^{\circ} \mathrm{C}$. On the other hand, S. officinalis was collected from the experimental fields in Hatay Mustafa Kemal University. Essential oil was obtained from dried leaves and flowers. A total of $25 \mathrm{~g}$ of each of the ground plant samples was used for the separate hydrodistillation experiment. A weighed sample weight was individually and carefully placed into a $1 \mathrm{~L}$ flask. Distilled water was then added until it covered the sample completely. The essential oils were then obtained by water- distillation for $3 \mathrm{hr}$ by using a Clevenger type apparatus according to European Pharmacopoeia method. The trial was repeated three times. Percentage essential oil yield was calculated according to dry weight of plant materials and amount of essential oils obtained. The Essential oils were dried over anhydrous sodium sulfate and stored in dark vial bottles at $+4^{\circ} \mathrm{C}$ until analysis (Türkmen and Mert 2020, Kara et al. 2021, Türkmen et al. 2021).

The components of the essential oils of the plants were determined by gas-chromatographic (GC-MS) method. Determination of essential oil components was carried out with Thermo Scientific ISQ Single Quadrupole model gas chromatographic device under the following conditions. TR-FAME MS model, 5\% Phenyl Polysilphenylene-siloxane, $0.25 \mathrm{~mm}$ inner diameter x $60 \mathrm{~m}$ length, $0.25 \mu \mathrm{m}$ film thickness column was used. Helium (99.9\%) was used as the carrier gas for Peer Review only at a flow rate of $1 \mathrm{ml} / \mathrm{min}$. Mass spectra were recorded at $70 \mathrm{eV}$, the mass range was from 1.2-1200 m/z. Scan Mode was used for data collection. The MS transfer line temperature was $250^{\circ} \mathrm{C}$, the MS ionization temperature was $220^{\circ} \mathrm{C}$, the injection port temperature was $220^{\circ} \mathrm{C}$, the column temperature was initially $50^{\circ} \mathrm{C}$ and the temperature was raised to $220^{\circ} \mathrm{C}$ with a rate of heat increase of $3^{\circ} \mathrm{C} / \mathrm{min}$. The structure of each compound was identified using mass spectra with the Xcalibur program (Wiley 9). The individual compositions were determined by comparing their retention index and with Wiley Library (Wiley Interscience, New York). The relative quantities of individual compounts were calculated with Xcalibur Report programme. The compounds were identified from the GC/MS spectra by comparison of their retention indices (RI) with homologous series of n-alkanes. Retention indices were determined using retention times of n-alkanes (C8-C40) injected under the same chromatographic conditions, co-injection with standards compared with those data from Wiley 9 comparison of fragmentation pattern in the mass spectra of each constituent with those data from Wiley 9 libraries. RI compared with the reported values. Identification of each individual compound was made by comparison of their retention times with those of authentic samples and by computer searching and matching with mass spectral data held in computer libraries (Asil 2018, Arpag et al. 2020, Türkmen 2021).

Data obtained from essential oil contents of Salvia spp. were subjected to ANOVA and means were compared using Duncan's multiple range test by using a SPSS statistical program (Version 24.0, IBM, USA). 


\section{Results and Discussion}

The essential oil content of $S$. aramiensis Rech. fil., S. fruticosa Mill., S. tomentosa Mill. and S. officinalis L. is presented in Table 1 and in Figs 1,2,3 and 4. Among the plants, S. aramiensis had significantly higher $(\mathrm{p}<0.001)$ essential oil content with $5.31 \%$ followed by $S$. fruticosa, $S$. officinalis and $S$. tomentosa with the ratio of $2.04,1.68$ and $1.40 \%$, respectively (Table 1). The essential oil content of $S$. aramiensis was reported to be 3.00, 2.20 and $1.30 \%$ by Sarer (1987), Karaman et al. (2007) and Arslan (2016), respectively. In the present study, in S. aramiensis essential oil content was detected highest compared to previous studies. Similarly, the essential oil content $(1.40 \%)$ of $S$. tomentosa was determined and found to be slightly higher than the findings of Arslan (2016).

Table 1. Essential oil content of Salvia species.

\begin{tabular}{ll}
\hline Name of plants & Essential oil content $(\%)$ \\
\hline S. aramiensis Rech. fil. & $5.31 \pm 0.90^{\mathrm{a}}$ \\
S. fruticosa Mill. & $2.04 \pm 0.23^{\mathrm{b}}$ \\
S. tomentosa Mill. & $1.40 \pm 0.05^{\mathrm{b}}$ \\
S. officinalis L. & $1.68 \pm 0.11^{\mathrm{b}}$ \\
$P$ & $* * *$ \\
\hline
\end{tabular}

Data are given as mean values \pm standard deviation. ${ }^{\mathrm{a}, \mathrm{b}}$ Means in the same column showing different small letters are significantly different $(* * * \mathrm{p}<0.001)$.

Chemical composition of the essential oils of four Salvia spp. leaves are presented in Table 2. The chromatograms were obtained and they are shown in Fig. 1,2,3 and 4. As expected, terpenes were detected as the dominant chemical class among all essential oils. Because, it is known that terpenes are the main components of essential oils (Aldred et al. 2009).

GC/MS analysis revealed that 29 (99.31\%), 33 (99.54\%), 28 (97.69\%) and 29 (99.45\%) components were detected for the essential oils of S. aramiensis, S. fruticosa, S. tomentosa and S. officinalis, respectively (Table 2). Terpenes constituted more than $90 \%$ the ratio of essential oil components. While eucalyptol was the main constituent for S. aramiensis (58.65\%), S. fruticosa $(34.97 \%)$ and $S$. tomentosa $(44.70 \%), \delta$-thujone was dominant component for $S$. officinalis $(33.83 \%)$ (Figs 1,2,3,4). It is known that eucalyptol, a terpenoid oxide, has a significant role in human health due to anti-inflammatory and antioxidant properties in various diseases (Seol and Kim 2016).

It is reported that $S$. aramiensis is located only in Hatay flora in Turkey (Davis 1982). Therefore it is important to evaluate this Salvia species in terms of being endemic to Hatay. In the essential oil of $S$. aramiensis, eucalyptol (58.65\%) and $\beta$-pinene (11.07\%) were identified as major components. These results are more or less compatible with the findings of Demirci et al. (2002), Kelen and Tepe (2008) and Askun et al. (2010). Other major components after eucalyptol and $\beta$-pinene were borneol (5.44\%), $\alpha$-pinene $(4.58 \%)$ and camphene $(4.53 \%)$, respectively but camphor and thujone were not detected in the essential oil of S. aramiensis (Table 2).

In the case of S. fruticosa essential oil, eucalyptol (34.97\%) and camphor (24.20\%) determined as the major components (Table 2). These findings are in agreement with the previous studies (Putievsky et al. 1992, Askun et al. 2010). It was reported that camphor has toxic properties while eucalyptol and camphor are significant chemicals in terms of their antimicrobial 
activities (Tirillini et al. 1996, Pattnaik et al. 1997, Tzakou et al. 2001). In S. fruticosa $\alpha$-terpineol (5.73\%), isobornyl acetate $(5.31 \%)$, camphene $(4.47 \%)$ and caryophyllene oxide $(4.47 \%)$ were identified as other major components in the essential oil (Table 2).

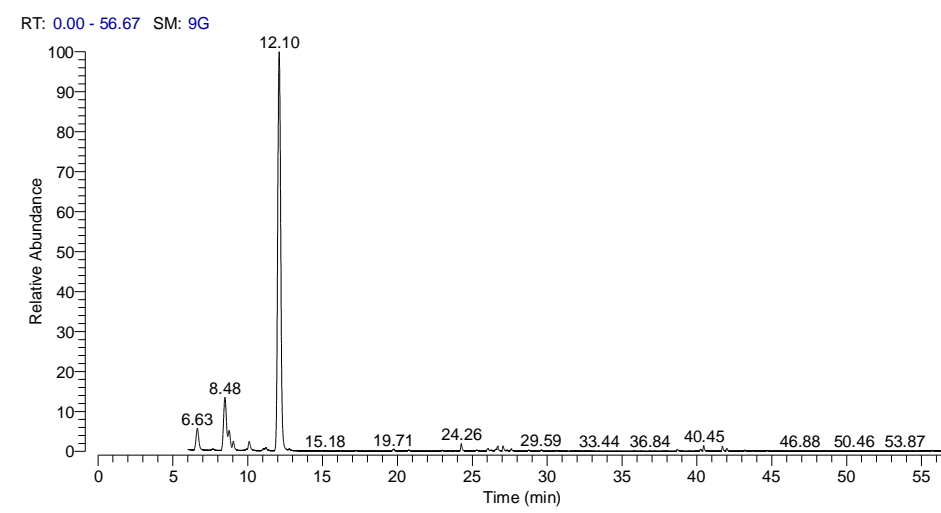

Fig. 1. GC-MS chromatogram of essentials oil of S. aramiensis Rech. fil

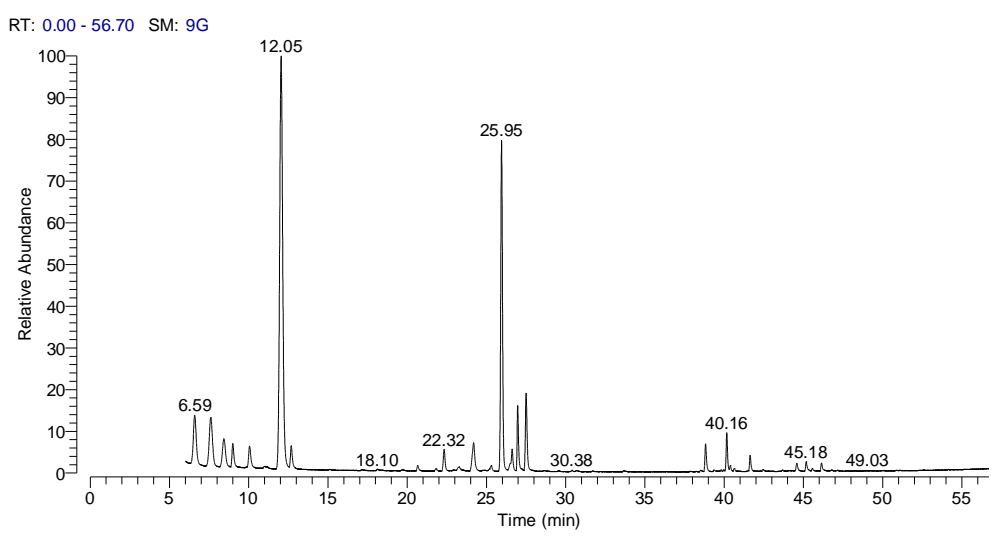

Fig. 2. GC-MS chromatogram of essentials oil of S. fruticosa Mill.

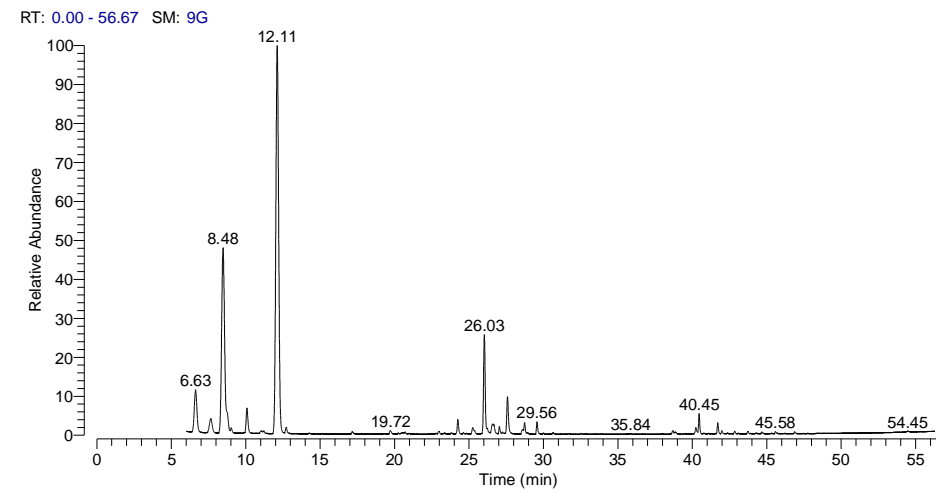

Fig. 3. GC-MS chromatogram of essentials oil of S. tomentosa Mill. 


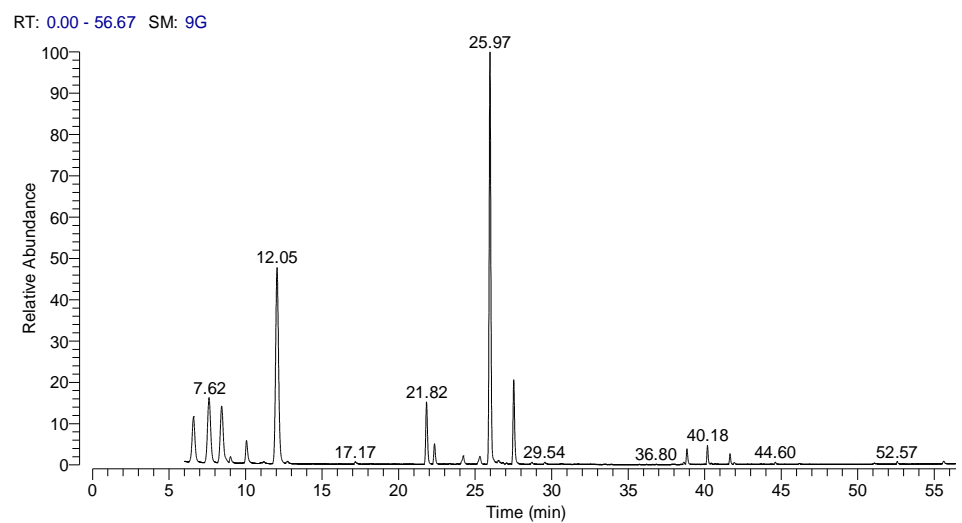

Fig. 4. GC-MS chromatogram of essentials oil of S. officinalis L.

Table 2. Chemical composition of the essential oil of Salvia species.

\begin{tabular}{|c|c|c|c|c|c|c|}
\hline \multirow[b]{2}{*}{ RT } & \multirow[b]{2}{*}{ Name of compounds } & \multirow[b]{2}{*}{ RI } & \multicolumn{4}{|c|}{ Area $(\%)$} \\
\hline & & & $\begin{array}{l}\text { S. aramiensis } \\
\text { Rech. fil. }\end{array}$ & $\begin{array}{l}\text { S. fruticosa } \\
\text { Mill. }\end{array}$ & $\begin{array}{c}\text { S. tomentosa } \\
\text { Mill. }\end{array}$ & S. officinalis $\mathrm{L}$. \\
\hline 6.59 & $\alpha$-Pinene ${ }^{\dagger}$ & 1069 & 4.58 & 3.91 & 4.43 & 0.76 \\
\hline 7.61 & Camphene $^{\dagger}$ & 1137 & 4.53 & 4.47 & 1.54 & 0.98 \\
\hline 8.43 & $\beta$-Pinene ${ }^{\dagger}$ & 1190 & 11.07 & 2.45 & 21.34 & 0.85 \\
\hline 8.99 & Myrcene $^{\dagger}$ & 1224 & 1.14 & 1.65 & 0.32 & 0.7 \\
\hline 10.05 & Limonene $^{\dagger}$ & 1283 & 1.44 & 1.53 & 2.27 & 1.07 \\
\hline 10.98 & Sabinene $^{\dagger}$ & 1330 & 1.47 & 0.19 & 0.34 & nd \\
\hline 11.13 & Terpinene $^{\dagger}$ & 1338 & 0.18 & 0.13 & 0.23 & 0.17 \\
\hline 12.04 & Eucalyptol $^{\dagger}$ & 1381 & 58.65 & 34.97 & 44.70 & 16.12 \\
\hline 12.68 & Cymene $^{\dagger}$ & 1410 & 0.06 & 1.53 & 0.5 & 1.06 \\
\hline 18.1 & 1-Octen-3-ol ${ }^{\S}$ & 1682 & 0.08 & 0.09 & 0.18 & 0.06 \\
\hline 19.65 & cis-Sabinene hydrate ${ }^{\dagger}$ & 1764 & 0.15 & 0.15 & 0.56 & 0.15 \\
\hline 20.52 & $\beta$-Bourbonene ${ }^{\dagger}$ & 1808 & nd & nd & 0.07 & nd \\
\hline 20.66 & Linalool $^{\dagger}$ & 1815 & 0.27 & 0.36 & 0.11 & 0.1 \\
\hline 22.32 & $\beta$-Thujone ${ }^{\dagger}$ & 1893 & nd & 1.7 & nd & nd \\
\hline 21.79 & $\delta$-Thujone ${ }^{\dagger}$ & 1869 & nd & nd & nd & 33.83 \\
\hline 22.89 & trans-Sabinene hydrate $^{\dagger}$ & 1919 & nd & nd & nd & 0.17 \\
\hline 23.27 & Alloaromadendrene ${ }^{\dagger}$ & 1936 & 0.12 & 0.32 & nd & nd \\
\hline 23.34 & $\alpha$-Campholenal* & 1939 & nd & nd & 0.07 & nd \\
\hline 24.19 & trans-Caryophyllene ${ }^{\dagger}$ & 1975 & nd & 2.13 & nd & 2.21 \\
\hline 24.25 & Terpinen-4-ol ${ }^{\S}$ & 1978 & nd & nd & 1.14 & nd \\
\hline 25.25 & Sabinyl acetate ${ }^{\precsim}$ & 2020 & nd & nd & 0.82 & nd \\
\hline 25.3 & Bornyl acetate ${ }^{\curlyvee}$ & 2023 & 0.51 & 0.33 & nd & 0.4 \\
\hline
\end{tabular}


Contd.

\begin{tabular}{|c|c|c|c|c|c|c|}
\hline \multirow[b]{2}{*}{$\mathrm{RT}$} & \multirow[b]{2}{*}{ Name of compounds } & \multirow[b]{2}{*}{ RI } & \multicolumn{2}{|l|}{ Area $(\%)$} & \multirow[b]{2}{*}{$\begin{array}{c}\text { S. tomentosa } \\
\text { Mill. }\end{array}$} & \multirow[b]{2}{*}{ S. officinalis L. } \\
\hline & & & $\begin{array}{l}\text { S. aramiensis } \\
\text { Rech. fil. }\end{array}$ & $\begin{array}{l}\text { S. fruticosa } \\
\text { Mill. }\end{array}$ & & \\
\hline 25.95 & Camphor $^{\dagger}$ & 2051 & nd & 24.2 & 8.67 & 21.46 \\
\hline 26.24 & Pinocarvone ${ }^{\ddagger}$ & 2063 & nd & nd & 0.07 & nd \\
\hline 26.66 & Elemol $^{\dagger}$ & 2080 & nd & nd & 0.58 & nd \\
\hline 26.77 & cis-Thujanol $^{\dagger}$ & 2085 & nd & nd & nd & 0.11 \\
\hline 26.97 & $\alpha$-Terpineol ${ }^{\dagger}$ & 2093 & 1.15 & 5.73 & 0.53 & 0.13 \\
\hline 27.0 & Borneol $^{\dagger}$ & 2094 & 5.44 & nd & 3.13 & 4.21 \\
\hline 27.5 & Isobornyl acetate ${ }^{ð}$ & 2113 & 0.38 & 5.31 & nd & nd \\
\hline 28.6 & Geranyl acetate ${ }^{\bar{z}}$ & 2151 & 1.02 & 0.08 & nd & nd \\
\hline 28.59 & Bicyclogermacrene $^{\dagger}$ & 2151 & nd & nd & 0.37 & nd \\
\hline 28.73 & Myrtenal* & 2155 & nd & nd & 0.95 & nd \\
\hline 29.53 & Myrtenol $^{\dagger}$ & 2182 & 0.23 & 0.06 & 1.06 & 0.04 \\
\hline 30.39 & exo-2-Hydroxycineole ${ }^{\S}$ & 2211 & 0.12 & 0.08 & nd & nd \\
\hline 30.7 & cis-Calamenene $^{\dagger}$ & 2221 & 0.1 & 0.08 & nd & 0.07 \\
\hline 31.68 & p-Cymen-8-ol ${ }^{\S}$ & 2254 & 0.18 & 0.05 & nd & 0.06 \\
\hline 33.66 & Gurjunenepoxide $^{\dagger}$ & 2340 & 0.24 & 0.07 & nd & nd \\
\hline 38.51 & Thymol $^{\dagger}$ & 2602 & nd & 0.12 & nd & nd \\
\hline 38.82 & Veridiflorol $^{\dagger}$ & 2613 & 0.35 & 1.79 & 0.35 & 7.65 \\
\hline 39.35 & Globulol $^{\dagger}$ & 2633 & 0.68 & 0.11 & nd & 0.05 \\
\hline 39.79 & Carvacrol $^{\dagger}$ & 2650 & nd & 0.14 & nd & 0.15 \\
\hline 40.16 & Caryophyllene oxide $^{\dagger}$ & 2663 & 2.04 & 4.47 & 1.1 & 3.98 \\
\hline 40.39 & Spathulenol $^{\dagger}$ & 2672 & 1.92 & 0.29 & 1.43 & 0.3 \\
\hline 41.64 & Humuladienone $e^{\ddagger}$ & 2717 & 0.75 & 0.98 & nd & nd \\
\hline 43.66 & Humulene $^{\dagger}$ & 2786 & 0.46 & 0.07 & 0.83 & 0.53 \\
\hline 52.55 & Manool $^{\dagger}$ & 3057 & nd & nd & nd & 2.08 \\
\hline
\end{tabular}

${ }^{\dagger}$ Terpene. ${ }^{\ddagger}$ Ketone. ${ }^{\circledR}$ Ester. ${ }^{\S}$ Alcohol. * Aldehyde.

Similar to $S$. aramiensis, eucalyptol $(44.70 \%)$ and $\beta$-pinene $(21.34 \%)$ constituted the main components for $S$. tomentosa (Table 2). On the other hand, camphor was not identified in $S$. aramiensis unlike the essential oil of $S$. tomentosa. Other major components for S. tomentosa. were followed by camphor $(8.67 \%), \alpha$-pinene $(4.43 \%)$ and borneol $(3.13 \%)$, respectively. These components are compatible with the results reported by Askun et al. (2010). However, researchers reported that $\alpha$-pinene and camphor were main compounds followed by borneol and eucalyptol.

Terpenes were found to be the major chemical class for S. officinalis (97\%). However, $\delta$ thujone $(33.83 \%)$ and camphor $(21.46 \%)$ were determined the main components for the essential oil of $S$. officinalis. As mentioned before, due to their toxic effects, camphor and thujone limits using of the sages as tea and spice in the food industry. In the essential oil obtained from the $S$. officinalis, other major compunds were eucalyptol $(16.12 \%)$, veridiflorol $(7.65 \%)$ and borneol (4.21\%), respectively. These results are in accordance with the findings of Putievsky et al. (1992). 
The essential oils of medicinal and aromatic plants contain a wide range of beneficial metabolites such as terpenoids, phenolic compounds vitamins and their derivatives. On the other hand, various toxic and carcinogenic substances can be found in the plants. In this respect, content and chemical composition of essential oil of some sage species consumed as tea and spice plants are important. In this study, the essential oil composition and content of S. officinalis L. as growing cultivated and 3 Salvia species growing naturally in Hatay province was investigated. Among these species, S. aramiensis, which has the highest essential oil content and does not contain toxic components such as camphor and thujone, is recommended to be cultivated and to expand its cultivation. Further studies should be done on the selection and cultivation of this plant.

\section{References}

Aldred EM, Buck C and Vall K 2009. Chapter 22-Terpenes. In: Pharmacology. Aldred EM, Buck C and Vall K (Eds), pp. 167-174. Churchill Livingstone, London.

Arpag OF, Duran N, Açikgül FC, and Türkmen M 2020. Comparison of Minimum Inhibitory Concentrations of Hypericum perforatum L. Essential Oils, $0.2 \%$ Chlorhexidine and 10\% Povidone-iodine Over Aggregatibacter actinomycetemcomitans and Porphyromonas gingivalis. J. Essential Oil Bearing Plants, 23: 6, 1192-1205.

Arslan M 2016. Cultivation potential of Salvia tomentosa and S. aramiensis under the Eastern Mediterranean conditions. Sci. Pap. Ser. A Agron. 59: 174-177.

Asil H 2018. GC-MS analysis of volatile components of Safranbolu and Kirikhan saffron (Crocus sativus L.) prepared by ultrasonic extraction. Fresenius Environ. Bull. 27(12B), 9557-9563.

Askun T, Baser HC, Tumen G and Kurkcuoglu M 2010. Characterization of essential oils of some Salvia species and their antimycobacterial activities. Turk. J. Biol. 34: 89-95.

Baser KHC 2002. Aromatic biodiversity among the flowering plant taxa of Turkey. Pure Appl. Chem. 74: $527-545$.

Böszörményi A, Héthelyi E, Farkas A, Horváth G, Papp N, Lemberkovics E and Szoke E 2009. Chemical and genetic relationships among sage (Salvia officinalis L.) cultivars and Judean sage (Salvia judaica Boiss.). J. Agric. Food Chem. 57(11): 4663-4667.

Cuvelier ME, Berset C and Richard H 1994. Antioxidant constituents in Sage (Salvia officinalis). J. Agric. Food Chem. 42(3): 665-669.

Davis PH 1982. Flora of Turkey and the Aegean Islands. Edinburgh University, Edinburgh. 948 pp.

Demirci B, Baser KHC and Tumen G 2002. Composition of the essential oil of Salvia aramiensis Rech. Fil. growing in Turkey. J. Flav. Fragr. 17: 23-25.

Jimenez J, Risco S, Ruiz T and Zarzuelo A 1986. Hypoglycemic activity of Salvia lavendulifolia. Planta Med. 52(4): 260-262.

Kara M, Soylu S, Türkmen M and Kaya DA 2020. Determination and antifungal activities of laurel and fennel essential oils against fungal disease agents of cypress seedlings. Tekirdağ Ziraat Fakültesi Dergisi, 17:2, 264-275.

Karaman S, İlçim A and Çömlekçioğlu N 2007. Composition of the essential oils of Salvia aramiensis Rech. fil. and Salvia cyanescens Boiss. \& Bal. Pak. J. Bot. 39 (1): 169-172.

Kelen M and Tepe B 2008. Chemical composition, antioxidant and antimicrobial properties of the essential oils of three Salvia species from Turkish flora. Bioresour. Technol. 99 (10): 4096-4104.

Lamaison JL, Petitjean-Freytet C and Carnat A 1991. Medicinal Lamiaceae with antioxidant properties, a potential source of rosmarinic acid. Pharm. Acta Helv. 66 (7): 185-8.

Lawrence BM 1998. Progress in essential oils-sage oil, Perfum. Flavor. 23: 47-52.

Manoguerra AS, Erdman AR, Wax PM, Nelson LS, Caravati EM, Cobaugh DJ, Chyka PA, Olson KR, Booze LL and Woolf AD 2006. Camphor Poisoning: An evidence-based practice guideline for out-of-hospital management. Clin. Toxicol. 44: 357-370. 
Mert M, Akişcan Y and Gençer O 2005. Genotypic and phenotypic relationships of lint yield, fibre properties and seed content in a cross of two cotton genotypes. Acta Agriculturae Scandinavica Section B: Soil Plant Sci. 55 (1): 76-80.

Pattnaik S, Subramanyam VR, Bapaji M and Kole CR 1997. Antibacterial and antifungal activity of aromatic constituents of essential oils. Microbios. 89: 39-46.

Pelkonen O, Abass K and Wiesener J 2013. Thujone and Thujone containing herbal medicinal products: Toxicological assessment. Regul. Toxicol. Pharmacol. 65(1): 100-107.

Putievsky E, Ravid U and Sanderovich D 1992. Morphological Observations and Essential Oils of Sage (Salvia officinalis L.) Under Cultivation. J. Essent. Oil Res. 4(3): 291-293.

Sarer E 1987. Güney ve İç Anadolu Bölgelerinde Yetişen Bazı Salvia Türlerinin Uçucu Yağları Üzerinde Araştırmalar. Doğa Tu. Tıp ve Ecz. D. 97-103.

Sener O, Arslan M, Demirel N and Uremis I 2009. Insecticidal effects of some essential oils against the confused flour beetle (Tribolium confusum du Val)(Col.: Tenebrinoidea) in stored wheat. Asian J. Chem. 21(5), 3995.

Seol GH and Kim KY 2016. Eucalyptol and Its Role in Chronic Diseases. Adv. Exp. Med. Biol. 929: 389398.

Shahabi S, Jorsaraei SGA, Moghadamnia AA, Zabihi E, Aghajanpour SM, Kani SNM, Pourbagher R, Hosseini SA, Esmaili M, Yoonesi AA, Zarghami A and Alinezhad F 2012. Central effects of Camphor on GnRH and sexual hormones in male rat. Int. J. Mol. Cell. Med. 1(4): 191-196.

Tepe B, Eminagaoglu O, Akpulat HA and Aydin E 2007. Antioxidant potentials and rosmarinic acid levels of the methanolic extracts of Salvia verticillata (L.) subsp. verticillata and Salvia verticillata (L.) subsp. amasiaca (Freyn \& Bornm.) Bornm. Food Chem. 100(3): 985-989.

Tirillini B, Velasquez ER and Pellegrino R 1996. Chemical composition and antimicrobial activity of essential oil of Piper angustifolium. Planta Med. 62: 372-373.

Türkmen M. and Mert A 2020. Farklı azot dozlarının kişniş (Coriandrum sativum L.) yaş herba uçucu yağ bileşenleri üzerine etkisi. Mustafa Kemal Üniversitesi Tarım Bilimleri Dergisi. 25: 3, 309-315.

Türkmen M, Kara M, Maral H and Soylu S 2021. Determination of chemical component of essential oil of Origanum dubium plants grown at different altitudes and antifungal activity against Sclerotinia sclerotiorum. J. Food Process Preserv.; 00:e15787.

Türkmen M. 2021.The effect of different Phenological periods and harvest times on the essential oil ratio and components of basil genotypes. J. Essent Oil-Bearing Plants. 24: 94-109.

Tzakou O, Pitarokili D, Chinou IB and Harvala C 2001. Composition and antimicrobial activity of the essential oil of Salvia ringens. Planta Med. 67: 81-83.

Yesilada E, Honda G, Sezik E, Tabata M, Fujita T, Tanaka T, Takeda Y and Takaishi Y 1995. Traditional medicine in Turkey V. Folk medicine in the inner Taurus Mountain. J. Ethnopharmacol. 46(3): 133-152. 